Article

\title{
Expression Analysis of Cell Wall-Related Genes in the Plant Pathogenic Fungus Drechslera teres
}

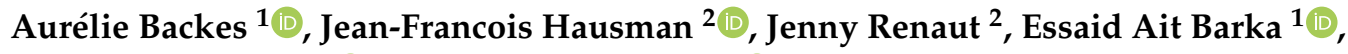 \\ Cédric Jacquard $1, t, * \mathbb{D}$ and Gea Guerriero ${ }^{2, t, * \mathbb{D}}$ \\ 1 Unité de Recherche Résistance Induite et Bio-protection des Plantes-EA 4707, Université de Reims \\ Champagne-Ardenne, UFR Sciences Exactes et Naturelles, SFR Condorcet FR CNRS 3417, Moulin de la \\ Housse-Bâtiment 18, BP 1039, 51687 Reims Cedex 2, France; aurelie.backes@univ-reims.fr (A.B.); \\ ea.barka@univ-reims.fr (E.A.B.) \\ 2 Environmental Research and Innovation (ERIN) Department, Luxembourg Institute of Science and \\ Technology (LIST), L-4940 Hautcharage, Luxembourg; jean-francois.hausman@list.lu (J.-F.H.); \\ jenny.renaut@list.lu (J.R.) \\ * Correspondence: cedric.jacquard@univ-reims.fr (C.J.); gea.guerriero@list.lu (G.G.) \\ + These authors contributed equally to this work.
}

Received: 14 February 2020; Accepted: 9 March 2020; Published: 12 March 2020

\begin{abstract}
Drechslera teres (D. teres) is an ascomycete, responsible for net blotch, the most serious barley disease causing an important economic impact. The cell wall is a crucial structure for the growth and development of fungi. Thus, understanding cell wall structure, composition and biosynthesis can help in designing new strategies for pest management. Despite the severity and economic impact of net blotch, this is the first study analyzing the cell wall-related genes in $D$. teres. We have identified key genes involved in the synthesis/remodeling of cell wall polysaccharides, namely chitin, $\beta$-(1,3)-glucan and mixed-linkage glucan synthases, as well as endo/exoglucanases and a mitogen-activated protein kinase. We have also analyzed the differential expression of these genes in $D$. teres spores and in the mycelium after cultivation on different media, as well as in the presence of Paraburkholderia phytofirmans strain PsJN, a plant growth-promoting bacterium (PGPB). The targeted gene expression analysis shows higher gene expression in the spores and in the mycelium with the application of PGPB. Besides analyzing key cell-wall-related genes, this study also identifies the most suitable reference genes to normalize qPCR results in $D$. teres, thus serving as a basis for future molecular studies on this ascomycete.
\end{abstract}

Keywords: Drechslera teres; barley net blotch; cell-wall-related genes; gene expression

\section{Introduction}

Barley is the fourth most-produced cereal in the world behind maize, wheat and rice. This crop is used mostly for animal feed (55\%-60\%) and by the malt industry (up to 35\%) [1]. Globally, twenty million tons of malt are produced per year, and barley is intended for beer production in breweries (https://www.planetoscope.com). However, the production of this monocotyledon may be compromised by the phytopathogen ascomycete Drechslera teres [2,3]. This filamentous fungus is responsible for net blotch, easily recognizable by the occurrence of brown necrotic lesions on leaves $[4,5]$. This disease negatively impacts barley physiology and development and thus causes important agronomic and economic losses. Because of the use of chemical products to control $D$. teres, the emergence of fungicide resistance is a matter of growing concern.

The cell wall is a crucial structure for fungal development, constituting the first physical barrier of protection and is, therefore, a target for antifungal agents [6]. Although the fungal cell wall composition 
varies from one species to another [6,7], it includes the fundamental components chitin, glucans, mannans and/or galactomannans and glycoproteins [8].

Chitin is one of the main structural components of the fungal cell wall. More specifically, this $\beta$-(1,4)-linked homopolymer of $N$-acetylglucosamine (GlcNAc) is synthesized by chitin synthases, CHSs. Chitin plays a crucial role in fungal morphogenesis and in hyphal tip growth [9]. In addition to chitin, several glucans have been identified in fungal cell walls, including $\beta$-(1,3)-glucans, mixed-linkage glucans, $\beta$-(1,6)-glucans and $\alpha$-(1,3)-glucans [10].

The Fks $A$ gene encodes a glycosyltransferase responsible for the synthesis of $\beta$-(1,3)-glucans. The inhibition of this gene disrupts the structural integrity of the cell wall and, therefore, impairs fungal development [6]. The majority of mannans and galactomannans decorate cell wall proteins, which are essential for cell wall formation [10]. Multiple classes of fungal cell wall proteins are present with diverse functions: glycosylphosphatidylinositol (GPI)-anchored proteins, transglycosidases, hydrolases including endo/exo- $\beta$-(1,3)-glucanase, chitinase, adhesins and hydrophobins. The roles of these proteins are to participate in cytokinesis, to remodel the cell wall and to ensure the adhesion to host cells and tissues [11].

In light of the crucial role played by the fungal cell walls as targets in the development of effective drugs to inhibit pathogens' growth, we here mine the genome of $D$. teres to identify key genes involved in cell wall biosynthesis $[12,13]$. The goal is to analyze their expression pattern in the spores and the mycelium grown on different media and in the presence/absence of the plant growth-promoting bacterium (PGPB) Paraburkholderia phytofirmans, strain PsJN [14-16]. The co-cultivation with a PGPB was investigated because of the increasing attention that biocontrol methods are playing as environmentally friendly strategies to protect crops against pests.

According to many studies, PsJN is able to induce plant growth with an antagonistic effect on pathogens' development. For instance, the bacterium restricts the spread of the gray mold disease caused by Botrytis cinerea $[17,18]$. PsJN-colonized tomato plants show an improved resistance against Verticillium sp. [19].

The remodeling of the cell wall has a crucial impact on the resistance of fungi to drugs [20]. Consequently, deciphering the regulation of cell wall-related genes in D. teres could inspire strategies aimed at controlling the spread of the disease. The present results constitute a resource for future molecular studies on the important phytopathogen $D$. teres. Despite the economic impact of the disease caused by $D$. teres, this is, to the best of our knowledge, the first study focusing on the cell wall-related genes of this pathogenic fungus.

\section{Materials and Methods}

\subsection{Media and Cultivation Conditions}

D. teres HE 019 (SAS BAYER Crop Lyon), the asexual form of the ascomycete fungus, was grown on different media, as hereafter described. Growing on these different media, $D$. teres presents several pathotypes. The abbreviations " + ", " - " and " $+/{ }^{\text {" }}$ are used to denote rich $(+)$, middle $(+/-)$ and poor $(-)$ media for the whole paper.

\subsubsection{Malt Extract Agar (MP)}

MP (-), a poor medium, is composed of $10 \mathrm{~g} / \mathrm{L}$ bacto malt extract and $15 \mathrm{~g} / \mathrm{L}$ agar. A volume of $150 \mu \mathrm{L}$ of spores suspension of $D$. teres at a concentration of 50,000 spores $/ \mathrm{mL}$ is spread on MP (-) medium. After 15 days at $20^{\circ} \mathrm{C}, D$. teres produces a small feather duster of approximately $1 \mathrm{~cm}$ of height and white in color on this medium. At this stage of development, a transfer from MP (-) media onto BOA (+) media is carried out to maintain $D$. teres and its pathogenicity. 


\subsubsection{Barley Oat Meal Agar (BOA)}

The medium composition is as follows: $18 \mathrm{~g} / \mathrm{L}$ meal agar, $50 \mathrm{~g} / \mathrm{L}$ milled leaves of barley and $17 \mathrm{~g} / \mathrm{L}$ agar. This enriched medium brings all nutritive elements to the growth and spore production of $D$. teres. The fungus was grown for 15 days on this medium with $12 \mathrm{~h}$ in darkness and $12 \mathrm{~h}$ under blue light near $\mathrm{UV}$ emission at $20^{\circ} \mathrm{C}$. Onesirosan and Banttari (1969) demonstrated that spore production was greatest when the fungal cultures were exposed to this wavelength [21]. Two inoculation conditions were tested including the mycelium of the fungus containing spores (first condition) or spore suspension (second condition). For the first type of inoculation, sterile water was deposited on the surface of the fungal mycelium to facilitate its harvest with a rod. For the second inoculation condition, mycelium and spores were filtered through sterile gauze tissues. The filtrate consisted mainly of spores. The concentration of the suspension was adjusted at $10^{5}$ spores/mL using a Malassez counting chamber (Marienfeld, Lauda-Königshofen, Germany).

\subsubsection{Potato Dextrose Agar (PDA)}

Co-culture of the fungus and PsJN was carried out on PDA (+/-) medium (39 g/L PDA, pH $4.5 \pm$ $0.2)$, a medium allowing both the development of fungi and bacteria. After 15 days of growth, a rod was passed on the whole mycelium surface together with sterile water.

\subsection{Bioinformatics}

The maximum likelihood phylogenetic analysis of CHS (protein sequences) was obtained with several CHSs from the following fungi: D. teres, Aspergillus nidulans [22], Alternaria alternata, Botrytis cinerea [23], Blumeria graminis [24], Fusarium graminearum, Tuber melanosporum [25] and Magnaporthe grisea [9]. The tree was generated with PhyML [26] and available at http://www.phylogeny.fr. The tree was visualized with the online software iTOL (http://itol.embl.de). The CHS sequences from $D$. teres, A. alternata, B. graminis, F. graminearum, T. melanosporum and M. grisea were obtained by blasting the A. nidulans CHSs (National Center for Biotechnology Information (NCBI) [27]. The identification of CHS domains was carried out with Motif Scan [28]. Sequences were aligned with Clustal Omega [29]. The prediction of the transmembrane domain was performed using the online programs TMHMM ( $\mathrm{v}$. 2.0) [30] and Phobius [31]. Protein identifications and corresponding accession numbers from NCBI are indicated in Table 1.

Table 1. List of the chitin synthase (CHS) protein accession numbers from the species used in this study.

\begin{tabular}{ccc}
\hline Species of Fungi & Protein Id & Accession Number \\
\hline \multirow{3}{*}{ Drechslera teres } & DtCHS1 & EFQ95838 \\
& DtCHS2 & EFQ92549 \\
& DtCHS3 & EFQ88914 \\
DtCHS4 & EFQ93986 \\
DtCHS5 & EFQ92060 \\
& DtCHS7 & EFQ96223 \\
& AnCHS1 & P30583 \\
Aspergillus nidulans & AnCHS2 & XP_660127 \\
& AnCHS3 & P78611 \\
& AnCHS4 & XP_663922 \\
& AnCHS5 & XP_658650 \\
& AnCHS7 & XP_018390769 \\
& AaCHS1 & XP_018389428 \\
Alternaria alternata & AaCHS2 & XP_018384374 \\
& AaCHS3 & XP_018387091 \\
& AaCHS4 & XP_018384599 \\
& AaCHS5 & XP_018384594 \\
\hline
\end{tabular}


Table 1. Cont.

\begin{tabular}{|c|c|c|}
\hline Species of Fungi & Protein Id & Accession Number \\
\hline \multirow{6}{*}{ Botrytis cinerea } & BcCHS1 & XP_024550705 \\
\hline & BcCHS2 & XP_001550325 \\
\hline & $\mathrm{BcCHS3}$ & XP_001557191 \\
\hline & BcCHS4 & XP_024546183 \\
\hline & BcCHS5 & XP_001545514 \\
\hline & BcCHS7 & XP_024549635 \\
\hline \multirow{6}{*}{ Blumeria graminis } & BgCHS1 & EPQ66343 \\
\hline & BgCHS2 & EPQ67341 \\
\hline & BgCHS3 & EPQ67743 \\
\hline & BgCHS4 & CCU76828 \\
\hline & BgCHS5 & AAF04279 \\
\hline & BgCHS7 & CCU74227 \\
\hline \multirow{6}{*}{ Fusarium graminearum } & FgCHS1 & CAC41025 \\
\hline & FgCHS2 & XP_011318411 \\
\hline & $\mathrm{FgCHS3}$ & PCD18709 \\
\hline & FgCHS4 & XP_011317052 \\
\hline & FgCHS5 & XP_011317820 \\
\hline & FgCHS7 & XP_011317804 \\
\hline \multirow{6}{*}{ Tuber melanosporum } & TmCHS1 & XP_002842229 \\
\hline & TmCHS2 & XP_002840530 \\
\hline & TmCHS3 & XP_002837735 \\
\hline & TmCHS4 & XP_002840095 \\
\hline & TmCHS5 & XP_002839897 \\
\hline & TmCHS7 & XP_002835817 \\
\hline \multirow{5}{*}{ Magnaporthe grisea } & $\mathrm{MgCHS} 2$ & CAA65275 \\
\hline & $\mathrm{MgCHS3}$ & CAA65276 \\
\hline & MgCHS4 & AAB71411 \\
\hline & MgCHS5 & BAA74449 \\
\hline & MgCHS7 & ACH58563 \\
\hline
\end{tabular}

\subsection{RNA Extraction and $c D N A$ Synthesis}

$D$. teres mycelium was crushed with liquid nitrogen using a mortar and a pestle. Spore suspensions, stored at $-80^{\circ} \mathrm{C}$, were lyophilized (Freeze Dryer Alpha $1 / 2-4$ Christ) for $12 \mathrm{~h}$ at $-55^{\circ} \mathrm{C}$, then milled using a ball mill MM400 (Retsch) for $2 \mathrm{~min}$ at $20 \mathrm{~Hz}$. The extraction of total RNA was carried out using the RNeasy Plant Mini Kit including the DNase I on-column digestion (Qiagen, Leusden, The Netherlands). The integrity of the obtained RNA was evaluated with an Agilent Bioanalyzer (Agilent, Santa Clara, CA, USA). RNA Integrity Numbers (RINs) were $>7$. The RNA quality and quantity were checked using a Nanodrop ND-1000 spectrophotometer (Thermo Scientific, Villebon-sur-Yvette, France) (A 260/280 and A 260/230 ratios between 1.9 and 2.2). In the case of contamination (ratio 260/230<2), samples were precipitated with ammonium acetate $\left(\mathrm{NH}_{4} \mathrm{OAc}\right)$ and washed in ethanol [32]. Subsequently, $1 \mu \mathrm{g}$ of extracted RNA was retro-transcribed using the Superscript II cDNA Synthesis kit (Invitrogen, Carlsbad, CA, USA), according to the manufacturer's instructions.

\subsection{Selection and Primer Design of Reference and Target Genes}

Eleven putative genes were chosen from the available literature as candidate reference genes [33-35]. These genes are actin (EFQ93811.1), aminopeptidase C ApsC (EFQ89971.1), cytochrome C oxidase Cos4 (EFQ89754.1), glyceraldehyde-3-phosphate dehydrogenase GAPDH (EFQ89753.1), glucokinase GlkA (EFQ96576.1), phosphofructokinase PfkA (EFQ89228.1), phosphoglucose isomerase PgiA (EFQ88542.1), secretion-associated GTP-binding protein SarA (EFQ89474.1), isocitrate dehydrogenase precursor IsdA (EFQ94718.1), histone H2B (EFQ87126.1) and ribosomal protein S14 RS14 (EFQ94228.1).

Thirteen target genes were chosen: mitogen-activated-protein kinase PTK1 (AF272831.1) [36], six isoforms of CHSs, i.e., CHS1, CHS2, CHS3, CHS4, CHS5, CHS7 (EFQ95838.1, EFQ92549.1, EFQ88914.1, 
EFQ93986.1, EFQ92060.1, EFQ96223.1, respectively), $\beta$-(1,3)-glucan synthase Fks $A$ (EFQ90969.1), endo- $\beta$-(1-3)-glucanase $E n g A$ (EFQ96294.1), three isoforms of putative exo- $\beta$-(1,3)-glucanases $E x g B$, ExgC and ExgD (respectively, EFQ93528.1, EFQ89593.1, EFQ92573.1) and the mixed-linkage glucan synthase celA (EFQ94510.1) [22]. All sequences, except PTK1, were retrieved by blasting the A. nidulans corresponding genes. Primers for qPCR amplification were designed with "Primer3Plus" (http: //www.bioinformatics.nl/cgi-bin/primer3plus/primer 3plus.cgi) and analyzed using the OligoAnalyzer tool from Integrated DNA Technologies (http://eu.idtdna.com/calc/analyzer). Primer efficiencies and specificities were calculated and checked using serial dilutions of cDNA with a factor $5(10,2,0.4,0.08$, $0.016,0.0032 \mathrm{ng} / \mu \mathrm{L})$. The characteristics of the primers of both reference and target genes are reported in Table 2.

Table 2. Description of the primers used for the qPCR analyses with details on the sequences, amplicons' length, Tm, amplification efficiency and regression coefficient.

\begin{tabular}{|c|c|c|c|c|c|}
\hline Name & Sequence $\left(5^{\prime}-3^{\prime}\right)$ & $\begin{array}{l}\text { Amplicon } \\
\text { Length (bp) }\end{array}$ & $\begin{array}{c}\text { Amplicon } \mathrm{Tm} \\
\left({ }^{\circ} \mathrm{C}\right)\end{array}$ & $\begin{array}{l}\text { PCR Efficiency } \\
(\%)\end{array}$ & $\begin{array}{c}\text { Regression } \\
\text { Coefficient }\left(\mathbf{R}^{2}\right)\end{array}$ \\
\hline Actin Fwd & ATGTTGGTGATGAGGCACAG & \multirow{2}{*}{123} & \multirow{2}{*}{84.4} & \multirow{2}{*}{87.5} & \multirow{2}{*}{0.999} \\
\hline Actin Rev & GCTCGTTGTAGAAGGTGTGATG & & & & \\
\hline ApsC Fwd & TCACCGATTCAGGTCTCAAC & \multirow{2}{*}{148} & \multirow{2}{*}{85.8} & \multirow{2}{*}{87.8} & \multirow{2}{*}{0.998} \\
\hline ApsC Rev & ATGTTGGGGCTCTTGATGTC & & & & \\
\hline Cos4 Fwd & GCACACTTCTCCCCAGAGC & \multirow[b]{2}{*}{104} & \multirow{2}{*}{87.8} & \multirow{2}{*}{89.6} & \multirow{2}{*}{0.999} \\
\hline $\operatorname{Cos} 4 \operatorname{Rev}$ & CCATCGCTTCTCGATATTGG & & & & \\
\hline GAPDH Fwd & AGGGCAAACTGAACGGTATC & \multirow{2}{*}{92} & \multirow{2}{*}{82.9} & \multirow{2}{*}{93.9} & \multirow{2}{*}{0.998} \\
\hline GAPDH Rev & GGCATCGAAAATGGAAGAGC & & & & \\
\hline GlkA Fwd & CGCTTGGAACTGCTTTCTTC & \multirow[b]{2}{*}{106} & \multirow[b]{2}{*}{86.8} & \multirow[b]{2}{*}{93.8} & \multirow{2}{*}{0.995} \\
\hline GlkA Rev & TGTAGGACGATTGGGTTTCG & & & & \\
\hline PfkA Fwd & GTTCCCAGCCCAGTTATTTG & \multirow[b]{2}{*}{93} & \multirow{2}{*}{81.9} & & \\
\hline PfkA Rev & AGCAACAGCGACTTCTTTGG & & & 91.3 & 0.998 \\
\hline PgiA Fwd & СААСТТССАССААСТТСТСG & & & & \\
\hline PgiA Rev & TTAGCAGACCACCAATGACG & 98 & 82.9 & 95.0 & 0.999 \\
\hline SarA Fwd & AGATGCCATTTCCGAGGAC & & & & \\
\hline SarA Rev & CCACACTGCACATGAAGACC & 116 & 86.4 & 92.4 & 0.997 \\
\hline IsdA Fwd & TCAAGAAGATGTGGCTGTCG & & & & \\
\hline IsdA Rev & GATGGTGGGGATGACAATG & 89 & 85.3 & 86.0 & 0.999 \\
\hline H2B Fwd & TACAAGGTCCTCAAGCAGGTC & & & & \\
\hline H2B Rev & AACACGCTCGAAGATGTCG & 96 & 83.8 & 90.6 & 0.997 \\
\hline RS14 Fwd & CACATCACCGATCTTTCTGG & & & & \\
\hline RS14 Rev & GTAATGCCGAGTTCCTTGC & 146 & 88.2 & 87.0 & 0.997 \\
\hline PTK1 Fwd & TGCTCCTAAACGCAAACTGC & & & & \\
\hline PTK1 Rev & CCGTCATGAATCCAGAGTTG & 93 & 84.2 & 92.0 & 0.999 \\
\hline CHS1 Fwd & GGACATCAAAAAGGGTGTCG & & & & \\
\hline CHS1 Rev & ATGCCTGGAAGAACCATCTG & 119 & 82.2 & 89.4 & 0.999 \\
\hline CHS2 Fwd & TCCAAGAGGGTATTGCGAAG & & & & \\
\hline CHS2 Rev & TGAATTTGAGGTCCGAGTCC & 102 & 82.3 & 102.0 & 0.988 \\
\hline CHS3 Fwd & GCCTGAAGCAAAAGAACAGC & & & & \\
\hline CHS3 Rev & AAATGCAGACTTCGGGGTTC & 90 & 83.2 & 91.4 & 0.999 \\
\hline CHS4 Fwd & TCATCATCTGCGACGGTATG & & & & \\
\hline CHS4 Rev & GAAAATGCCTGAACCTCGTG & 115 & 83.3 & 94.0 & 0.996 \\
\hline CHS5 Fwd & CAAGTGCGTTCGTCAACAAG & & & & \\
\hline CHS5 Rev & GTCCAAGAAACTCGGCAAAC & 107 & 83.4 & 93.0 & 0.999 \\
\hline CHS7 Fwd & CGGAAAAGAACTCGCTCATC & & & & \\
\hline CHS7 Rev & GGAAAGCAGAGAATCGCAAC & 141 & 85.8 & 91.2 & 0.998 \\
\hline FksA Fwd & AGTTTCTTACGCTGGCAACC & 146 & 895 & 890 & 0999 \\
\hline FksA Rev & CTTCCTTGGTACAGGGAATCTG & 146 & 89.5 & 89.0 & 0.999 \\
\hline EngA Fwd & TCAAGTGTGGAAGGGTATCG & 107 & 848 & 033 & 0994 \\
\hline EngA Rev & AGCCGTAATGGAAGTGATGG & 107 & 84.8 & 93.3 & 0.994 \\
\hline ExgB Fwd & TGGATGATGGGAGATGAGTG & & & & \\
\hline ExgB Rev & GGCCTTTGTTTGACCAAGTG & 90 & 82.0 & 102.8 & 0.996 \\
\hline ExgC Fwd & TAAACACAGGCGGATGGTTC & & & & \\
\hline ExgC Rev & CACGAATTCCAGTGGTCTTG & 145 & 88.1 & 91.3 & 0.994 \\
\hline ExgD Fwd & GACGCAAACGAAGAGAATCC & 101 & 863 & 88.2 & 0.998 \\
\hline ExgD Rev & TGGTAGTAAATCGCCCTGTG & 101 & 86.3 & 88.2 & 0.998 \\
\hline $\begin{array}{l}\text { celA Fwd } \\
\text { celA Rev }\end{array}$ & $\begin{array}{l}\text { CATTACCGCCCTTTTGTCAC } \\
\text { ATGAAGAACCACGCAAGACC }\end{array}$ & 117 & 81.0 & 88.7 & 0.998 \\
\hline
\end{tabular}

2.5. qPCR: Analysis of the Results and Statistics

A liquid handling robot (epMotion 5073, Eppendorf, Hamburg, Germany) was used to dispense the reaction mixture and cDNA in 384-well plates. The Takyon Low ROX SYBR MasterMix dTTP Blue 
Kit (Eurogentec, Liège, Belgium) was used for qPCR. The reactions were run in technical triplicates and repeated on four independent biological replicates. PCR was performed on a ViiA 7 Real PCR System (Thermo Scientific, Villebon-sur-Yvette, France) using the following conditions: initial denaturation at $95{ }^{\circ} \mathrm{C}$ for $10 \mathrm{~min}, 40$ cycles of denaturation at $95^{\circ} \mathrm{C}$ for $15 \mathrm{~s}$, primer annealing at $60{ }^{\circ} \mathrm{C}$ for $60 \mathrm{~s}$. At the end of the experiment, the specificity of the amplified products was checked by the analysis of the melting curve. qBase ${ }^{\text {PLUS }}$ (version 3.2, Biogazelle, Ghent, Belgium) was used to calculate gene expression. Cos4 and PgiA were identified as the most stable genes in the experimental set-up chosen and as sufficient for normalization. A one-way ANOVA with Tukey's post-hoc test was performed with IBM SPSS Statistics v19 (IBM SPSS, Chicago, IL, USA) to determine the statistically significant differences among groups.

A hierarchical clustering using uncentered absolute correlation and complete linkage was performed with Cluster 3.0 (Pearson correlation coefficient threshold $=0.83$ ) [37]. The heat map was visualized with Java TreeView (http://jtreeview.sourceforge.net/) [38].

\section{Results and Discussion}

\subsection{Analysis of D. teres Phenotypes on Several Media}

D. teres shows varying phenotypes according to the culture media used (Figure 1). On MP (-) medium, the fungus develops a white structure, similar to a feather duster (Figure 1a) as described in the literature [39]. This structure appears when the fungus is searching for nutritive resources. On this medium, spore production is not possible since their formation and subsequent germination require, in most filamentous fungi, the availability of nutrients in the culture medium, such as sugars, amino acids and inorganic salts [40].

On BOA (+), the color of the mycelium becomes black resulting from sporulation (Figure 1b,c). When exposed to wavelengths between 355 and $495 \mathrm{~nm}$, followed by a dark period on rich medium, the fungus produces a great number of spores [41,42]. Spores of $D$. teres are cylindrical in shape with round ends, having a length from 25 to $300 \mu \mathrm{m}$ and thickness from 7-11 $\mu \mathrm{m}[4,5]$. Due to their septa, these spores are recognizable from other fungi (Figure 1d) [43]. The spores presenting less than two septa will not germinate and cannot penetrate plant tissues [44]. D. teres infects the plants via the spores, the reproductive structures, which are dispersed largely by the wind or rain and often over long distances.

On PDA (+/-), D. teres covers the entire surface of the culture medium within seven days, denoting a rapid growth (Figure $1 \mathrm{e}$ ). On this medium, D. teres produces a very small number of spores (Figure $1 \mathrm{~g}$ ) as compared to the BOA (+) medium (Figure 1b) [45]. Since the PDA (+/-) medium is suitable for the development of bacteria and fungi, a co-culture of $D$. teres with PsJN, was performed. When grown alone on the PDA (+/-) medium (Figure 1e), D. teres has a fluffy mycelium with some feather dusters characteristic of this fungus [46]. Under co-cultivation with PsJN, D. teres has a different phenotype than when growing alone on PDA (+/-) (Figure 1f). Indeed, the mycelium of D. teres is less fluffy and fruiting bodies are present at the periphery, probably to provide a protective barrier against PsJN. PsJN protects indeed several crops against damages caused by different abiotic or biotic stresses and promotes plant growth [17-19,47-50]. According to our results, this strain seems to have no antifungal effect and is, therefore, unable to prevent the development of $D$. teres.

The results suggest that the variability of the phenotypes observed on the different media would be accompanied by changes in the expression of cell-wall-related genes, since the fungal cell wall is a dynamic structure accommodating the different growth stages and morphologies. 

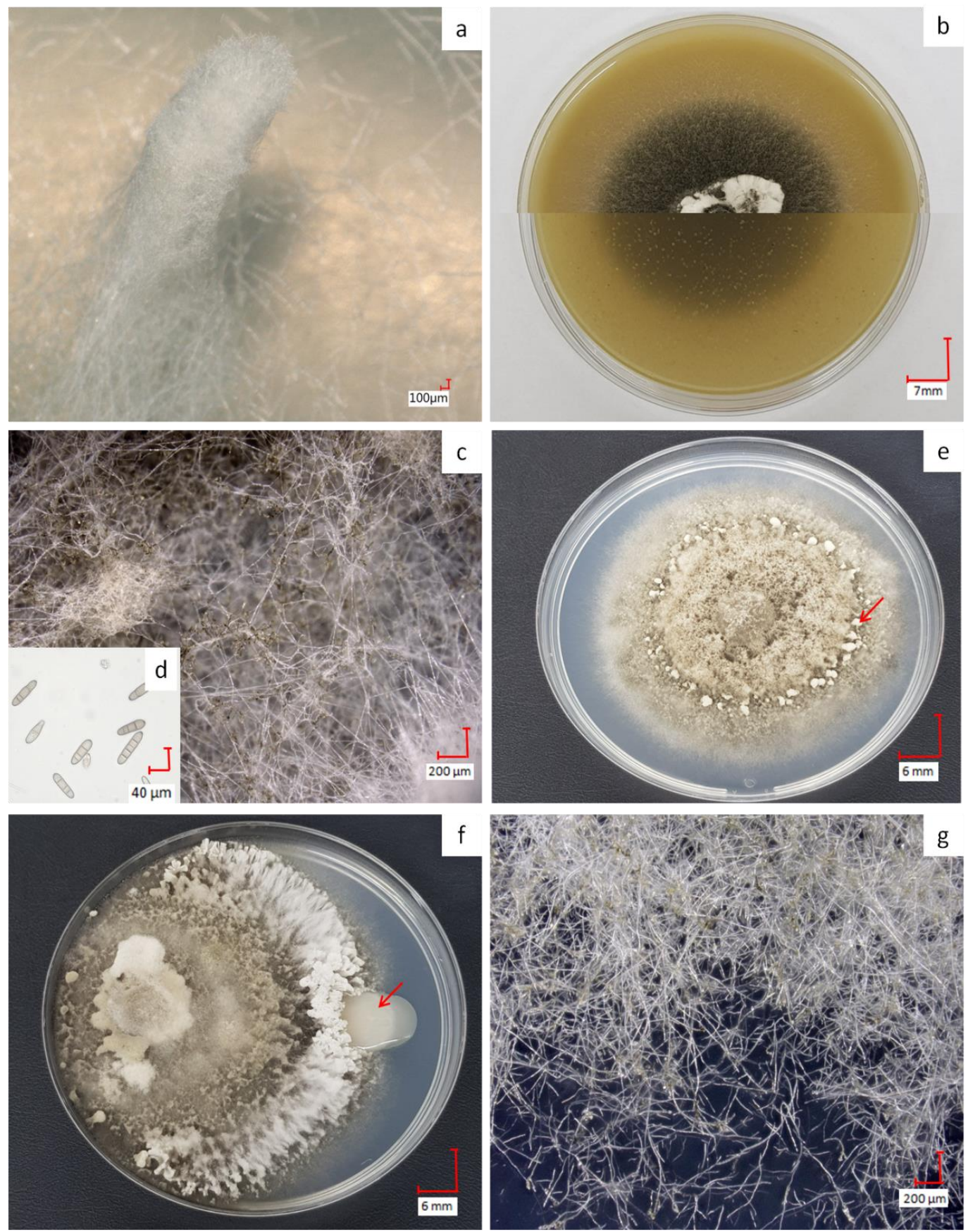

Figure 1. Phenotypes of $D$. teres on malt extract agar (MP) (-) with the typical feather duster (a); aspect of $D$. teres on BOA $(+)$ with top and bottom views of the Petri dish in the two halves of the image $(\mathbf{b})$; mycelium of $D$. teres on BOA $(+)(\mathbf{c})$; transversely septate conidia produced by $D$. teres on BOA $(+)$ (d) and $D$. teres phenotype on PDA (+/-) medium with fruiting bodies (red arrow in e), aspect in the presence of PsJN (f) and mycelium on PDA (+/-) (g). The co-culture condition shows that PsJN (red arrow in $\mathrm{f})$ has no visible effect on the mycelium's growth on PDA $(+/-)$ medium. The pictures $(\mathbf{a}, \mathbf{c}, \mathbf{d}, \mathbf{g})$ were obtained with a 3D Keyence VHX-2000F microscope.

\subsection{Identification of CHS Genes in D. teres and Phylogenetic Analysis}

The fungal cell wall is a complex and dynamic structure that protects the cell from environmental stresses [10,51]. Given the important role played in fungal physiology, the cell wall is considered as a suitable target for antifungal drugs [6]. 
Chitin is the most important structural component of the fungal cell wall [9-11,52,53]. The enzymes catalyzing the synthesis of chitin are CHSs, which are members of glycosyltransferases from family 2 (GT2), like cellulose synthases. CHSs are able to transfer $N$-acetyl-D-glucosamine from an activated sugar donor (UDP-N-acetyl-D-glucosamine) to an elongating chitin chain $[6,54]$.

In previous work, seven chitin synthase genes $\operatorname{chs} A, \operatorname{chs} B, \operatorname{chs} C, \operatorname{chs} D, \operatorname{chs} E, \operatorname{csm} A$ and $\operatorname{csm} B$ were identified in the model organism $A$. nidulans encoding CHSs of Classes I, II, III, IV, V VI and VII [22]. The presence of multiple CHSs in many fungi suggests that several CHSs can be used for chitin production at different stages of the fungal life-cycle [10].

According to the classification proposed by Chigira et al. [55] and Choquer et al. [56], in our study, DtCHS1, DtCHS2, DtCHS3, DtCHS4, DtCHS5 and DtCHS7 encode CHSs from Class I, Class II, Class III, Class IV, Class V and Class VII, respectively [55,56]. These enzymes are localized in the plasma membrane [9].

BLASTp analysis carried out using the CHS protein sequences of $A$. nidulans identified six CHSs in D. teres (hereafter referred to as DtCHS1, 2, 3, 4, 5 and 7 for the protein sequences and DtCHS1, 2, 3, 4, 5 and 7 for the genes) (Table 1). The maximum likelihood phylogenetic analysis carried out using CHS full-length protein sequences from several classes of fungi, notably Dothideomycetes, Sordariomycetes and Leotiomycetes, allowed assigning a phylogenetic relatedness for the D. teres CHS with known orthologs from other species (Figure 2).

The phylogenetic analysis demonstrates the existence of six CHS classes (Figure 2). Class I, II and IV are present in all fungi, while Classes III, V and VII are particular to filamentous fungi [57]. The number of $\mathrm{CHS}$ genes changes according to the species. Most fungal species contain between three and six CHS genes [58]. For example, three CHS are present in S. cerevisiae, four in Candida albicans and eight in A. nidulans [59,60].

CHS1 and CHS2 have overlapping functions in septum formation in A. nidulans [61]. In the same way, CHS1 is crucial for infection-related morphogenesis, since $90 \%$ of the chs $1 \mathrm{M}$. oryzae mutants have no septum and, therefore, display severe defects in conidium morphology [9]. CHS1 is also essential for cell wall integrity in Candida albicans [59]. Class IV enzymes contribute to the synthesis of the bulk cell wall chitin [57]. In M. oryzae, CHS1 is important for virulence and plays specific roles during conidiogenesis and appressorium formation. CHS2, CHS3, CHS4 and CHS5 are essential for plant infection and CHS6 is dispensable for pathogenesis [9]. Therefore, individual CHS genes play several roles in hyphal growth, pathogenesis, conidiogenesis and appressorium development.

BLASTp analyses and motif searches reveal similarities between the six identified CHSs from D. teres and other fungal CHSs (Table 3 and Figures 3 and 4). Structurally, CHS1, CHS2 and CHS3 are more similar to each other than to other CHSs in D. teres. As in A. nidulans and other filamentous fungi, Class V CHSs in D. teres have myosin motor-like domains at the N-terminus [11,62]. Myosins are actin-dependent molecular motors and play roles in several cellular processes. More specifically, the head myosin domain binds to actin in an ATP-dependent manner and generates force by ATP hydrolysis [63].

CHSs have several conserved domains which are considered as signature sequences since they are found in all CHSs [64]. Most of the amino acids of these signature motifs were found to be essential for activity [65]. CHSs contain the conserved EDR motif and the pentapeptide QRRRW (Figure 4) which was reported also in CHSs from the chordate Branchiostoma floridae [66]. The importance of these motifs has been studied in yeast. Thereby, in Saccharomyces cerevisiae, mutations of the QRRRW motif lead to a significant decrease in CHSs activity [58]. By comparing the amino acid sequences of the six D. teres CHSs in NCBI, DtCHS1/DtCHS2, DtCHS2/DtCHS3 and DtCHS4/DtCHS5 have similarities, with 43\%, 44\% and 45\% identity, respectively (Figures 3 and 4). DtCHS4 and DtCHS5 are closer with respect to the similarity of amino acid sequences. This sequence similarity is also confirmed by the phylogenetic tree (Figure 2). 


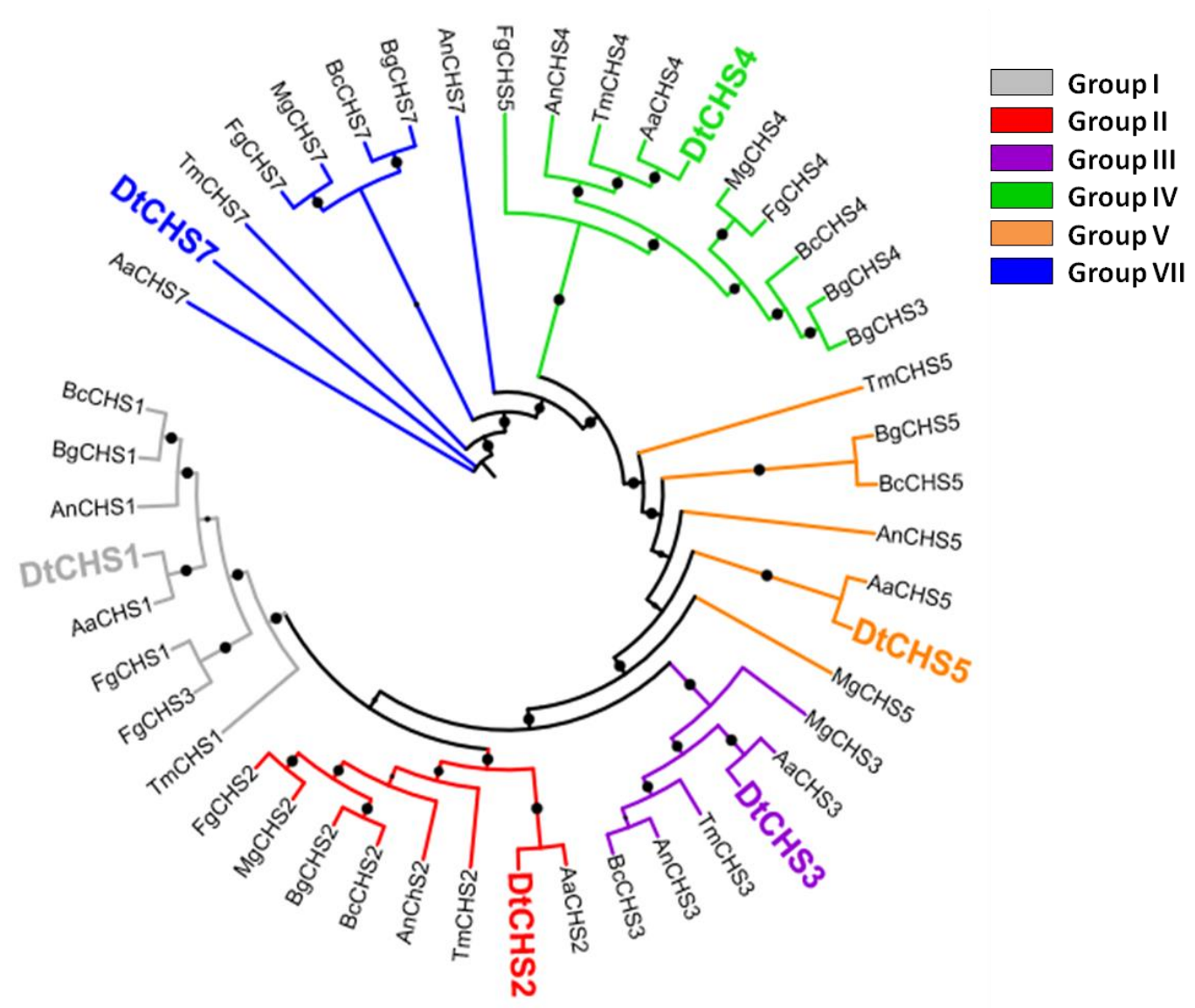

Figure 2. Maximum likelihood phylogenetic tree (bootstraps: 100) of chitin synthases (CHS) from $D$. teres $(D t), A$. nidulans $(A n)$, A. alternata $(A a), B$. cinerea $(B c), B$. graminis $(B g), F$ graminearum $(F g)$, T. melanosporum (Tm) and M. grisea $(\mathrm{Mg})$. The protein accession numbers are indicated in Table 2. Bootstraps $>80 \%$ are represented as black circles on the branches. The bootstrap \% value increases with the circle size.

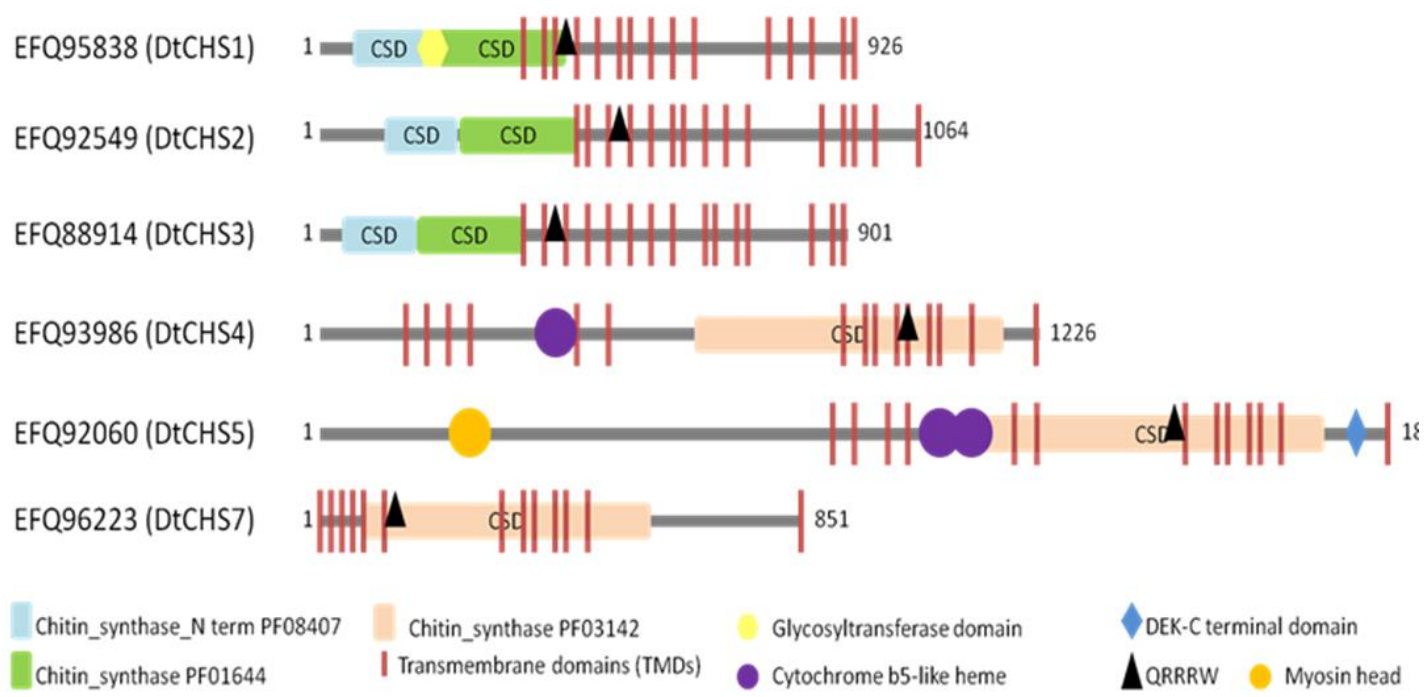

Figure 3. Schematic representation showing the domain organization of the six putative CHSs from $D$. teres. Highlighted motifs were identified with Motifscanner and predicted transmembrane domains were identified with Phobius and TMHMM programs. CSD: Chitin Synthase Domain. 
Table 3. D. teres CHS with predicted transmembrane domains (TMDs), deduced protein lengths and predicted domains.

\begin{tabular}{|c|c|c|c|}
\hline CHS & $\begin{array}{l}\text { No. of } \\
\text { TMDs }\end{array}$ & Length & Domains ( $E$-values) \\
\hline CHS1 & 15 & 926 & $\begin{array}{c}\text { Glycosyltransferase }(0.0011) \text {, Chitin synthase }\left(1,7 \mathrm{e}^{-152}\right) \text {, Chitin } \\
\text { synthase N-terminal }\left(1,5 \mathrm{e}^{-53}\right)\end{array}$ \\
\hline CHS2 & 15 & 1064 & Chitin synthase $\left(3,3 \mathrm{e}^{-153}\right)$, Chitin synthase $\mathrm{N}$-terminal $\left(3,1 \mathrm{e}^{-43}\right)$ \\
\hline CHS3 & 15 & 901 & Chitin synthase $\left(4,6 \mathrm{e}^{-123}\right)$, Chitin synthase N-terminal $\left(4 \mathrm{e}^{-53}\right)$ \\
\hline CHS4 & 15 & 1226 & Cytochrome b5-like heme $\left(6.8 \mathrm{e}^{-10}\right)$, Chitin synthase $(0)$ \\
\hline CHS5 & 13 & 1844 & $\begin{array}{l}\text { Cytochrome b5-like heme }\left(2.8 \mathrm{e}^{-15}\right) \text {, Chitin synthase (0), DEK-C } \\
\text { terminal domain term }\left(5.3 \mathrm{e}^{-24}\right) \text {, Myosin-head }\left(3.9 \mathrm{e}^{-165}\right)\end{array}$ \\
\hline CHS7 & 13 & 851 & Chitin synthase $\left(9.9 \mathrm{e}^{-7}\right)$ \\
\hline
\end{tabular}

DtCHS4
DtCHS5
DtCHS7
DtCHS3
DtCHS1
DtCHS2
DtCHS4
DtCHS5
DtCHS7
DtCHS3
DtCHS1
DtCHS2

DtCHS4
DtCHS5
DtCHS7
DtCHS3
DtCHS1
DtCHS2

DtCHS4
DtCHS5
DtCHS7
DtCHS3
DtCHS1
DtCHS2

DtCHS4

DeCHS5

DtCHS7

DtCHS3

DtCHSI

DeCHS2

DtCHS4

DeCHS5

DtCHS7

DtCHS3

DtCHS1

DeCHS2

DeCHS4

DtCHS5

DtCHS7

DtCHS3

DtCHS1

DtCHS2

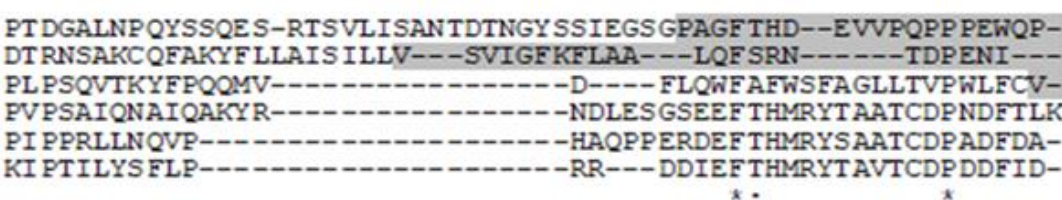

FGYP-1DKFI IATVPAYTE DEESLRRAIDS AARMK-YDDKRK - YQLVTH SVGRTRRIKSVLDESSA PKVVI I MPCYKE I PEILLRTCDS LVDCE-Y--NGYNLRPA------MY--NRH TELLIA ITYYNE DKVLT ARTLHGVMQNIR DIVNLK ER FTLRQK-------L FAKPRH TELFIVITMYNE EDELF ARTMI GVIKANIEYMNSRT RGYKLRQN-------I -GNQRETEVFIAVTMYNENEIDFTRTMHGVMONISHFCSRM $:$ :

LI LI ICDGMIKGH-GEDLT TPEVCL SMMKDHAVLPHEVQAFSYVAVAS ---GSKRHNMAK LLVIVCDGMI IGQ-GNDKP TPRIVL DI LGVPEA--TD PDPLS FESL GE---GQRQHNMGK KSE----- WWNKGGPAWQKIVVCLVFDGID PCDKGT LDLLATVGIYQDGIMKKKDIDGNE NSK------TWGK--DAWKKIVVCVVSDGRAKINPRT RAVLAALGVYQDGIAKQ QVNGKD KSR----- TWGK--DGWQKIVVCI IADGRGKVHPRT LDAIAAMGCFQEGIAKNHVNQKE : :

IYSGFYDY GENTRI PTEKQQRVPVMLVVKCGTPDEAKKSKPGNRGKRDSQIILMSFLQKV CYSGLYEVHG-_-_---HIVPFLVVVKI GKPSE--VSKPGNRGKRDSOI I LMRFLNRV VPLTLDSY PKSI DVIYRSCRIT-_-_.-.---- ISRFP HGGKRH CQKRTFKLIDKI TVAHI FEY TTQLSVT PNQQLIR-_._-_._-_-- PHDDSASTLPPVQY-I FCLKQKVTAHIYEYTTQMTL DIKKGVVG--.---VTAHVYEYTTQVSL DSDLKFKG$\cdot$ $:$ :

MF DERMTELEFEMFNGIWKITGISPDFYEIVLMVDADTKVFPDSLTHMISAMVKDPDIMG HYNLPMSP LELEMH HQIRN I IGVNP TFYEFL LQIDADTEVAP DAATRFVAAFLH DTRLLA YS--EYLKRNDNLFVLFID SDCILDKTCIQN FMYEME LKPGS KKANM----------LA NS--KKINSHRWLFTAI--GRILNPEVCI---LLDAGTKPGP KSLLAL WEGFYNDKDLGG NQ--KKIN SHRWFEQAF--GTVLDPNVCV---LIDAGTKPGKDSVYQLWKAFDLEPMCAG NS--KLLNSHRWEFNAF--GRALNPNVCI---LLDVGTKPGP KALYHLWKAFDT DSSVAG

LCGETKIANKR----DSWVSMIQVFEYFISH HLARSFESVFGGVTCLPGCFCIYRIKAP 955 ICGETALTNAK----SSFVTMMVYEYFISHNLTRAFBSLFGSVICLPGCFTMYRIRAA 1476 QT GVITST TEK-----NSL ITLLQDMEYVHGQLFERSVESGCGAVTCLPGALTMLRFSAF 356 ACGEIHAMLGKGWKNLLNP LVAAQNFEYKISN ILDRPLESSFGYVSVLPGAFSAYRYRAI 450 ACGEIKAMLVH-GKKLLNP LVATQNFEYRMSN IMDRPLESAFGFISVLPGAFSAYRYVAL 492 AAGEIKAGKGKAWL GLLNP LVASQNFEYKMSN ILDRPLESVFGYITVLPGALSAYRYHAL 574

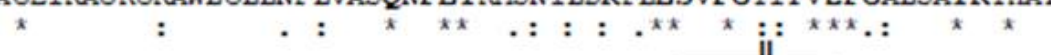

KGGQNYWVPI---LANP----DIVEHYSENVVDTLHKKALLLLGBDRYLSTLM-LKTF PK ESGKPL------FVSK----EVVEEYQQIRVDTLHMKNLLHL GEDRFLTLL-MKHH PK

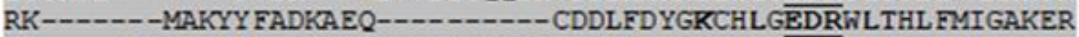
MG-----R PLEQYF HGDHT LAKILGK-KGIE GMNIF-KKNMMF LABDR I LCFE LVAKAGSK QNDKTGQG PLEKYF AGEKMHG-------ANAGI F-TANMYLAEDR I LCFE LVSKRNCH QNDHTGHG PLSQYFKGETLHG--------QDADVF-TANMYLAEDR I LCWE LVAKRSEQ $\star \overline{x+\pi} *$.

Figure 4. Cont. 
III

\begin{tabular}{|c|c|c|}
\hline DtCHS4 & RKQVFVPQAVCKTTVPDEFKVLLSQRRRWINSTIHNLMELVL--------------V & 1050 \\
\hline DtCHS5 & YKTKYTMRAHAWTVAPDSWSVFMSQRRRWINSTIHNLIELIP--------------L & 1567 \\
\hline DtCHS3 & WH LTYIKASKGETDVPEDAAELI GQRRRWLNGSFAAGIYALLHFGRMYKSGHNLIRMFF F & 563 \\
\hline DtCHS1 & WI LQYVKSATGETDVPT TMAEFI SQRRRWLNGSFFAAVYALAHSFDI FRSDHS FLRKTMF & 602 \\
\hline \multirow[t]{2}{*}{ DtCHS2 } & WVLKYVKAATGETDVPDAVPEFI SQRRRWLNGAFFAAVYSLLHFKQVWATDHT IWRKILL & 684 \\
\hline & 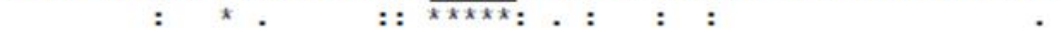 & \\
\hline DtCHS4 & $--\mathrm{R}------$ DLCGTFC---FSMQFVVEVELMGTLVL PA-----A-----------IAF & \\
\hline $\begin{array}{l}\text { DtCHS5 } \\
\text { DtCHS7 }\end{array}$ & 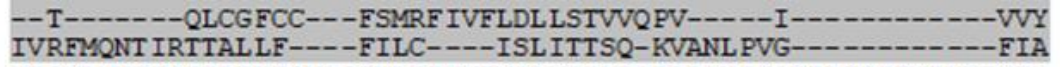 & \\
\hline DtCHS3 & HI QMLYNT FQT ILTWFSMASFWLTTVVIMSLVGTKTGDRDAW PFGNTA TPI FNTVVTYIY & 623 \\
\hline DtCHS1 & LVEFVYQT ISMI FAWFALGNFFLVF RILTA----SLQNE-----LGTVGKVLFI I FEWLY & \\
\hline DtCHS2 & $\begin{array}{l}\text { HI EFVYQFVQLLFT FFSLANFYLTFYFVAG----SLADPEMD PFGHNI GKI IFY ILRYTC } \\
\star:\end{array}$ & 740 \\
\hline DtCHS4 & 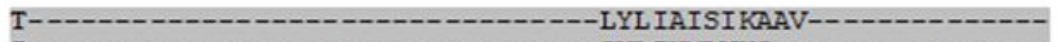 & 10 \\
\hline DtCHS5 & - & \\
\hline DtCHS7 & I $-\cdots$ & 50 \\
\hline DtCHS3 & LGFLVLQF ILAFGNRPKGSRWSYLI SFCVFGLIQLYIVILSI YLVVQAFTNPTSQKLDTS & 683 \\
\hline DtCHS1 & IAVLITCF ILSLGNRPQGSNKWYMSMVYFWC I IMSYLMFASVFITVRSVQGQIRANNGFN & 713 \\
\hline DtCHS2 & TL LICMQF ILSMGNRPQGAKKMFFW SMI IYG I IMAYT TFASFYIVIVQLRDPK------- & 793 \\
\hline DtCHS4 & $\cdots-\infty$ LHAA PVI PL ILLALI LGLPAI LI I ITAHRWSYVAWMFVYLLSLP IWNFVL & \\
\hline DtCHS5 & - PDVVPVTAF ILLGAI YGLQAI IFI-IRRKWEMIGWMI I YI FATPVFAFGL & \\
\hline DtCHS7 & - LYFGAKL GRYKIML- & 53. \\
\hline DtCHS3 & SPEAFAQSFFSSDGVGIII IALGAT FGLYYVASFLYMDPWHMFTSFPQYLLIMSSYINIL & 743 \\
\hline DtCHS1 & VAD-----LFKDKI FATIVISLLSTYMWLVVSI I FL DPWHMFTSFFQYLLMTP TYINIL & 768 \\
\hline \multirow[t]{2}{*}{ DtCHS2 } & AEK-----SLGSNVFTNLIVSTATT IGLYFLMSFMYL DPWHMFTSSAQYFALLPSYIATL & \\
\hline & : & \\
\hline DeCHS4 & PAYAFWKFDDFSWGDTRKTAGEKTKKAG-----------LEYEGEFDSSKI TMRRWHDFE & 1194 \\
\hline DtCHS5 & PLYSFWYMDDFSWGNTRVVTGEKGQKVV-----------VSDEGKFDPSVI PKKRWEEYQ & 1707 \\
\hline DtCHS7 & MVYGI FTAGQRTWGGPRADAGSADT-----QTSPQE---AIEAAEATGDDLNVV-PETEK & 582 \\
\hline DtCHS3 & NVYAFSNWHDVSWGTKGSDKADALP-SAKTEKGSDGKHNVIEEPDLPQADIDSQ----FE & 798 \\
\hline DtCHS1 & NVYAFCNTHDITWGTKGDDKAEKL-PSVVTKAD--G--KADIQAPTDDADLNTQ----YE & 819 \\
\hline \multirow[t]{2}{*}{ DeCHS2 } & QVYAFCNTHDITWGTKGDNVAKTDLGDARGKTK--N--VVELEMPSEQLDIDSG----YD & 900 \\
\hline & $:: * \star$ & \\
\hline DtCHS4 & 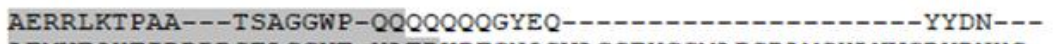 & 1226 \\
\hline DtCHS5 & AEMWEQHTIRDDRSEASGYT-YATRKPFGNQSVAGSEYGGMAPSRAMSHLNVGRYDNHS- & 1765 \\
\hline DtCHS7 & ASAEAHKH ---- RP -- GAI PLQPSDNIEGRF ------- AAA ----- E-RLPNGWYQQAND & 623 \\
\hline DtCHS3 & ATVKRALA----PY--VPPVESDEKTLEDSY-------KSF-----RTHLCTAWIGSN-- & 838 \\
\hline DtCHS1 & TELRVFSA----KWKEEKKI PSPSEKQEDYY-------KGF-----RSGVVLFWMFCN-- & 861 \\
\hline DtCHS2 & EALRNLRD----RVEVPEPPISESQQQEDYY-------RAV-----RTYMVVIWMISN-- & 942 \\
\hline
\end{tabular}

Figure 4. Partial amino acid sequence alignment of the six D. teres CHSs showing the conserved chitin synthase domain (highlighted) and "QRRRW"/"EDR" motifs (underlined). Amino acids indicated with bold characters are those conserved in all CHSs listed here. I-III represent subdomains where conserved amino acids appear at high frequencies.

\subsection{Expression Analysis of Cell Wall-Related Genes in D. teres}

The software geNorm ${ }^{\text {PLUS }}$ [67] was used to analyze gene expression stability across different samples of $D$. teres: spores and mycelium on BOA $(+)$, mycelium on MP $(-)$, and mycelium on PDA $(+/-)$ in the presence or absence of the bacterium. The stability and transcript levels of the eleven candidate reference genes actin, ApsC, Cos4, GlkA, PfkA, PgiA, SarA, IsdA, H2B, GAPDH and RS14 were investigated with geNorm ${ }^{\text {PLUS }}$. Cos 4 and PgiA were identified as the best two transcripts for use in normalization of the data (Supplementary Figure S1).

The attention was focused on key genes involved in fungal cell wall biosynthesis. Besides CHSs, genes coding for enzymes involved in $\beta$-(1,3;1,4)-glucan and $\beta$-(1,3)-glucan synthesis were investigated. Indeed, $\beta$-(1,3)-glucan is relevant since it accounts for $65-90 \%$ of the total $\beta$-glucan content [68].

The $\beta$-(1,3)-glucan hydrolyzing enzymes can be separated into exo- $\beta-(1,3)$-glucanases and endo- $\beta-(1,3)$-glucanases according to their activities [68]. Endo- $\beta-(1,3)$-glucanases cut within the chain of glucans, whereas exo- $\beta-(1,3)$-glucanases cleave the residues of glucose at the end of the chain $[69,70]$. During fungal growth, $\beta$-(1,3)-glucanases are essential for the remodeling of the cell 
wall [69]. $\beta$-(1,3)-glucans are synthesized by a glucan synthase complex, which uses UDP-glucose as a substrate and extrudes $\beta$-(1,3)-glucan chains [70]. Fks $A$ encodes the catalytic subunits of the glucan synthase complex and is cell-cycle-regulated [6,71].

The cell wall of ascomycetes also contains $\beta-(1,3 ; 1,4)$-glucan accounting for $10 \%$ of the glucan content in the $A$. nidulans cell wall $[35,72]$. celA encodes a putative mixed-linkage glucan synthase in $A$. nidulans [22]; one ortholog was found in D. teres and was used in this study.

We also considered a gene encoding a protein kinase, PTK1, which was shown to be required for conidiation, appressoria formation and pathogenicity in D. teres [36].

The hierarchical clustering of the heat map (Figure 5) shows that the CHS genes studied group in different clusters. CHS3, CHS4, CHS5 and CHS7 show a higher expression in spores and in the mycelium grown in the presence of the bacterium. This suggests that the bacterium induces the expression of specific $\mathrm{CHSs}$ in the phytopathogenic fungus. This phenomenon could be explained by an effect on the cell wall of the fungus. Indeed, PGPB is able to produce different types of cell-wall-lysing enzymes including chitinases, proteases, cellulases and $\beta$-(1,3)-glucanases [73,74]. The fungus could respond to PsJN by increasing the expression of CHSs in the attempt to restore the structural integrity of its cell wall.

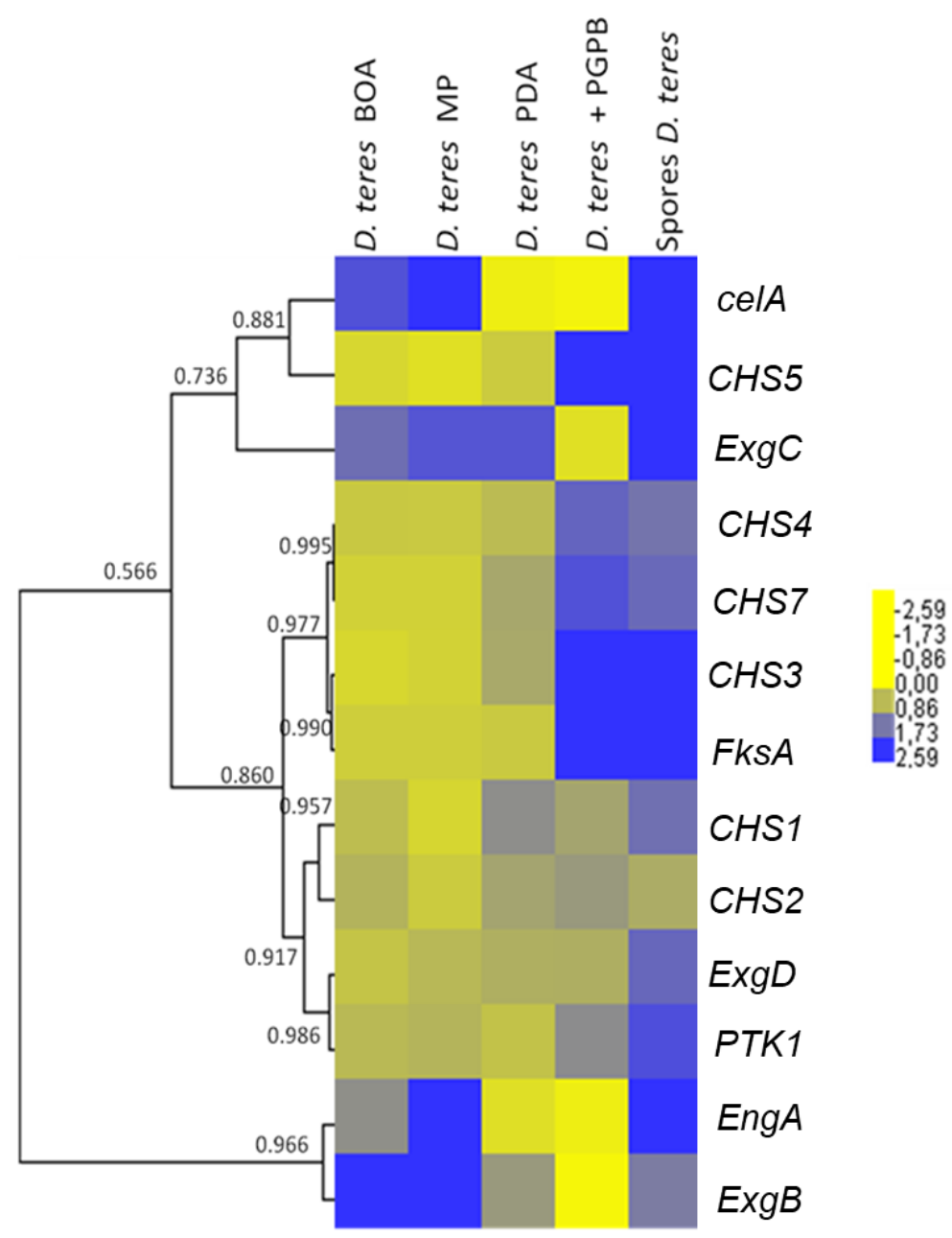

Figure 5. Heatmap hierarchical clustering with correlation coefficients of genes related to cell wall synthesis in $D$. teres. The heat map hierarchical clustering was generated using Pearson correlation in complete linkage.

Some CHS genes, such as CHS1 and CHS2, showed a tendency towards decreased expression on the poor medium MP (-) (Figures 5 and 6). This finding may indicate that these genes have a 
role in vegetative growth and the lower expression reflects the slower mycelium growth rate in a nutrient-poor environment.

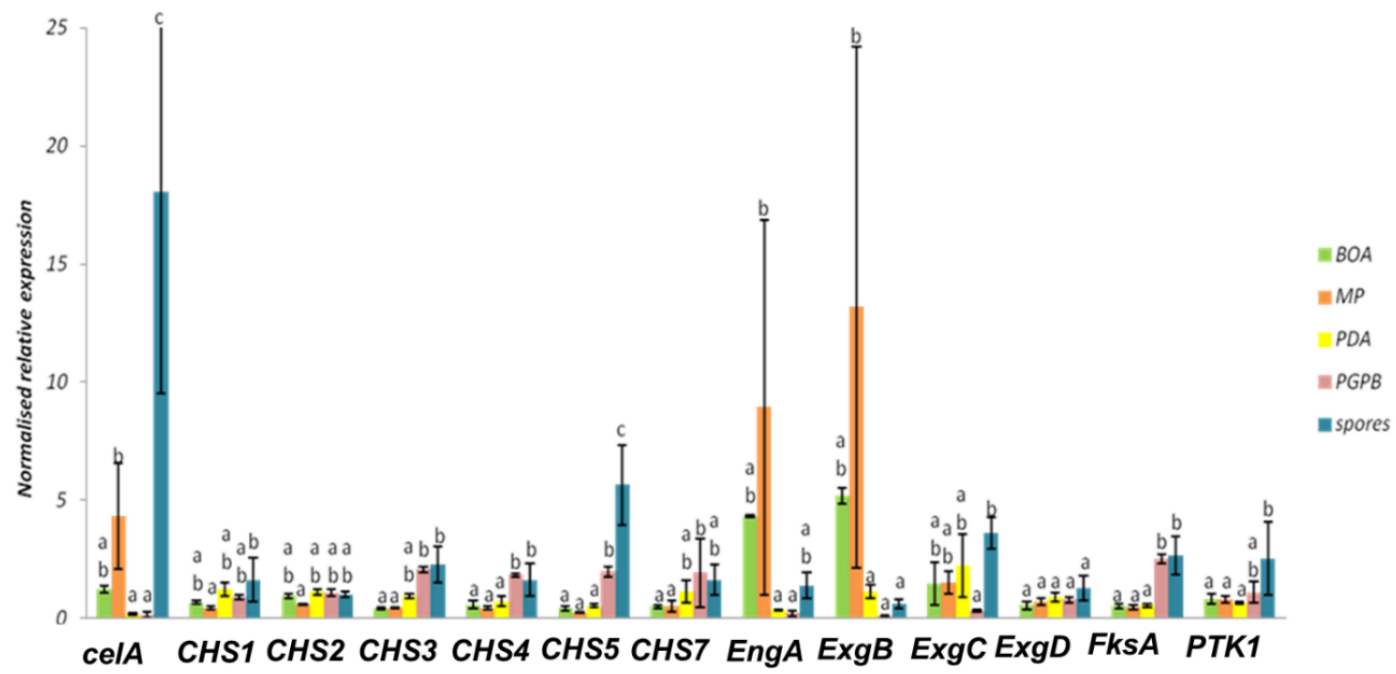

Figure 6. Normalized relative expression of cell wall genes of $D$. teres cultivated on different media. Different letters indicate statistically different values $(p$-value $<0.05)$ among the groups of the one-way ANOVA with Tukey's post-hoc test. Error bars represent the standard deviation of four independent biological replicates.

In D. teres, EngA is more expressed in the mycelium cultivated on the poor medium (MP (-) medium) (Figures 5 and 6). Likewise, the exo- $\beta$-(1,3)-glucanases $\operatorname{Exg} B$ is expressed at higher levels on the poor medium (MP (-) medium) (Figures 5 and 6). However, the differences are not statistically significant and only show a trend.

Fks $A$ is more expressed in spores and the mycelium with PsJN (Figures 5 and 6). According to Figure 6, the expression of celA is significantly higher in $D$. teres spores, as compared to the other conditions.

PTK1 has a slightly larger expression in the spores as compared to the other experimental conditions (Figures 5 and 6). This is in agreement with the reported role of PTK1 in conidiation [36].

Our results show that the expression of CHS4, CHS5 and FksA is higher in the mycelium cultivated on PDA (+/-) medium with PsJN, as compared to the growth on BOA (+), MP (-) and PDA (+/-) (Figure 6). According to Figure 1, PsJN has an effect on the phenotype of $D$. teres. This could be due to a possible secretion of hydrolytic enzymes by PsJN, acting on the integrity of the fungal cell wall $[73,74]$. $D$. teres could also perceive PsJN as a stress and thus strengthen its cell wall.

This hypothesis will have to be confirmed and validated by future experiments.

\section{Conclusions}

To the best of our knowledge, this is the first study devoted to the cell wall-related genes of $D$. teres. We identify key genes involved in the biosynthesis/remodeling of $D$. teres cell wall and differentially expressed in spores and/or in the mycelium depending on the culture media used. We also identify some cell wall biosynthetic genes induced by PsJN, a plant growth-promoting bacterium. Since PsJN seems to disturb fungal growth, it is reasonable to hypothesize that it could produce cell wall degrading enzymes causing a response in $D$. teres at the gene level. Additionally, we propose a list of potential candidate reference genes for qPCR analysis in $D$. teres. Our study paves the way to follow-up studies aiming at a functional characterization of cell wall genes of this economically relevant pathogen.

Supplementary Materials: The following is available online at http://www.mdpi.com/2073-4425/11/3/300/s1, Figure S1: Ranking of eleven candidate reference genes in $D$. teres according to the parameter M computed by geNorm $^{\text {PLUS }}$. The increase in stability of the candidate genes is determined by a decrease in the M value. 
Author Contributions: A.B., C.J. and G.G. conceived and designed the experiments; A.B. performed the experiments; A.B. and G.G. analyzed the data; A.B., G.G., C.J. and E.A.B. wrote the paper. J.-F.H. and J.R. provided feedback and contributed to interpreting and discussing the results. All authors have given approval to the final version of the manuscript.

Funding: This research received no external funding.

Acknowledgments: This work was supported by grand-Reims and Grand-Est Region. The authors gratefully acknowledge BAYER SAS Lyon for providing the D. teres HE 019 strain, and more specifically Marie-Pascale Latorse, Stéphane Brunet and Catherine Wantier for their technical assistance and participation in this study.

Conflicts of Interest: The authors declare no conflicts of interest.

\section{References}

1. Kangor, T.; Sooväli, P.; Tamm, Y.; Tamm, I.; Koppel, M. Malting barley diseases, yield and quality—responses to using various agro-technology regimes. Proc. Latv. Acad. Sci. Sect. B Nat. Exact Appl. Sci. 2017, 71, 57-62. [CrossRef]

2. Campbell, G.F.; Crous, P.W.; Lucas, J.A. Pyrenophora teres f. maculata, the cause of Pyrenophora leaf spot of barley in South Africa. Mycol. Res. 1999, 103, 257-267.

3. McLean, M.S.; Howlett, B.J.; Hollaway, G.J. Epidemiology and control of spot form of net blotch (Pyrenophora teres f. maculata) of barley: A review. Crop Pasture Sci. 2009, 60, 303-315. [CrossRef]

4. Lightfoot, D.J.; Able, A.J. Growth of Pyrenophora teres in planta during barley net blotch disease. Australas. Plant Pathol. 2010, 39, 499-507. [CrossRef]

5. Liu, Z.; Ellwood, S.R.; Oliver, R.P.; Friesen, T.L. Pyrenophora teres: Profile of an increasingly damaging barley pathogen. Mol. Plant Pathol. 2011, 12, 1-19. [CrossRef] [PubMed]

6. Bowman, S.M.; Free, S.J. The structure and synthesis of the fungal cell wall. BioEssays News Rev. Mol. Cell. Dev. Biol. 2006, 28, 799-808. [CrossRef] [PubMed]

7. Georgopapadakou, N.H.; Tkacz, J.S. The fungal cell wall as a drug target. Trends Microbiol. 1995, 3, 98-104. [CrossRef]

8. Yoshimi, A.; Miyazawa, K.; Abe, K. Cell wall structure and biogenesis in Aspergillus species. Biosci. Biotechnol. Biochem. 2016, 80, 1700-1711. [CrossRef]

9. Kong, L.A.; Yang, J.; Li, G.-T.; Qi, L.L.; Zhang, Y.J.; Wang, C.F.; Zhao, W.S.; Xu, J.-R.; Peng, Y.L. Different chitin synthase genes are required for various developmental and plant infection processes in the rice blast fungus Magnaporthe oryzae. PLoS Pathog. 2012, 8, e1002526. [CrossRef]

10. Free, S.J. Fungal cell wall organization and biosynthesis. Adv. Genet. 2013, 81, 33-82.

11. Gow, N.A.R.; Latge, J.-P.; Munro, C.A. The fungal cell wall: Structure, biosynthesis, and function. Microbiol. Spectr. 2017, 5, 1-25.

12. Ellwood, S.R.; Liu, Z.; Syme, R.A.; Lai, Z.; Hane, J.K.; Keiper, F.; Moffat, C.S.; Oliver, R.P.; Friesen, T.L. A first genome assembly of the barley fungal pathogen Pyrenophora teres f. teres. Genome Biol. 2010, 11, 1-14. [CrossRef] [PubMed]

13. Wyatt, N.A.; Richards, J.K.; Brueggeman, R.S.; Friesen, T.L. Reference assembly and annotation of the Pyrenophora teres f. teres Isolate 0-1. G3 Genes Genomes Genet. 2018, 8, 1-8.

14. Beneduzi, A.; Ambrosini, A.; Passaglia, L.M.P. Plant growth-promoting rhizobacteria (PGPR): Their potential as antagonists and biocontrol agents. Genet. Mol. Biol. 2012, 35, 1044-1051. [CrossRef]

15. Esmaeel, Q.; Jacquard, C.; Clément, C.; Sanchez, L.; Barka, E.A. Genome sequencing and traits analysis of Burkholderia strains reveal a promising biocontrol effect against grey mould disease in grapevine (Vitis vinifera L.). World J. Microbiol. Biotechnol. 2019, 35, 1-15. [CrossRef]

16. Kloepper, J.W.; Ryu, C.-M.; Zhang, S. Induced systemic resistance and promotion of plant growth by Bacillus spp. Phytopathology 2004, 94, 1259-1266. [CrossRef]

17. Barka, E.A.; Gognies, S.; Nowak, J.; Audran, J.-C.; Belarbi, A. Inhibitory effect of endophyte bacteria on Botrytis cinerea and its influence to promote the grapevine growth. Biol. Control 2002, 24, 135-142. [CrossRef]

18. Miotto-Vilanova, L.; Jacquard, C.; Courteaux, B.; Worthman, L.; Michel, J.; Clément, C.; Barka, E.A.; Sanchez, L. Burkholderia phytofirmans PsJN confers grapevine resistance against Botrytis cinerea via a direct antimicrobial effect combined with a better resource mobilization. Front. Plant Sci. 2016, 7, 1-15. [CrossRef] 
19. Sharma, V.K.; Nowak, J. Enhancement of verticillium wilt resistance in tomato transplants by in vitro co-culture of seedlings with a plant growth promoting rhizobacterium (Pseudomonas sp. strain PsJN). Can. J. Microbiol. 1998, 44, 528-536. [CrossRef]

20. Beauvais, A.; Fontaine, T.; Aimanianda, V.; Latgé, J.-P. Aspergillus cell wall and biofilm. Mycopathologia 2014, 178, 371-377. [CrossRef]

21. Onesirosan, P.T.; Banttari, E.E. Effect of light and temperature upon sporulation of Helminthosporium teres in culture. Phytopathology 1969, 59, 906-909.

22. de Groot, P.W.J.; Brandt, B.W.; Horiuchi, H.; Ram, A.F.J.; de Koster, C.G.; Klis, F.M. Comprehensive genomic analysis of cell wall genes in Aspergillus nidulans. Fungal Genet. Biol. 2009, 46, 72-81. [CrossRef] [PubMed]

23. Causier, B.E.; Milling, R.J.; Foster, S.G.; Adams, D.J. Characterization of chitin synthase from Botrytis cinerea. Microbiology 1994, 140, 2199-2205. [CrossRef]

24. Zhang, Z.; Hall, A.; Perfect, E.; Gurr, S.J. Differential expression of two Blumeria graminis chitin synthase genes. Mol. Plant Pathol. 2000, 1, 125-138. [CrossRef] [PubMed]

25. Balestrini, R.; Sillo, F.; Kohler, A.; Schneider, G.; Faccio, A.; Tisserant, E.; Martin, F.; Bonfante, P. Genome-wide analysis of cell wall-related genes in Tuber melanosporum. Curr. Genet. 2012, 58, 165-177. [CrossRef] [PubMed]

26. Guindon, S.; Gascuel, O. A simple, fast, and accurate algorithm to estimate large phylogenies by maximum likelihood. Syst. Biol. 2003, 52, 696-704. [CrossRef] [PubMed]

27. National Center for Biotechnology Information (NCBI). Available online: https://blast.ncbi.nlm.nih.gov/Blast. cgi (accessed on 2 March 2020).

28. Motif Scan. Available online: https://myhits.isb-sib.ch/cgibin/motif_scan (accessed on 10 January 2020).

29. Clustal Omega. Available online: https://www.ebi.ac.uk/Tools/services/web/toolresult.ebi?jobId=clustaloI20181219-133935-0983-50653640-p1m (accessed on 10 January 2020).

30. TMHMM (v. 2.0). Available online: http://www.cbs.dtu.dk/services/TMHMM-2.0/ (accessed on 10 January 2020).

31. Phobius. Available online: http://phobius.sbc.su.se/ (accessed on 10 January 2020).

32. Mangeot-Peter, L.; Legay, S.; Hausman, J.F.; Esposito, S.; Guerriero, G. Identification of reference genes for RT-qPCR data normalization in Cannabis sativa stem tissues. Int. J. Mol. Sci. 2016, 17, 1-10. [CrossRef]

33. Bohle, K.; Jungebloud, A.; Göcke, Y.; Dalpiaz, A.; Cordes, C.; Horn, H.; Hempel, D.C. Selection of reference genes for normalisation of specific gene quantification data of Aspergillus niger. J. Biotechnol. 2007, 132, 353-358. [CrossRef]

34. Dilger, M.; Felsenstein, F.G.; Schwarz, G. Identification and quantitative expression analysis of genes that are differentially expressed during conidial germination in Pyrenophora teres. Mol. Genet. Genom. 2003, 270, 147-155. [CrossRef]

35. Guerriero, G.; Silvestrini, L.; Legay, S.; Maixner, F.; Sulyok, M.; Hausman, J.F.; Strauss, J. Deletion of the celA gene in Aspergillus nidulans triggers overexpression of secondary metabolite biosynthetic genes. Sci. Rep. 2017, 7, 1-8. [CrossRef]

36. Ruiz-Roldán, M.C.; Maier, F.J.; Schäfer, W. PTK1, a mitogen-activated-protein kinase gene, is required for conidiation, appressorium formation, and pathogenicity of Pyrenophora teres on barley. Mol. Plant-Microbe Interact. MPMI 2001, 14, 116-125. [CrossRef] [PubMed]

37. Eisen, M.B.; Spellman, P.T.; Brown, P.O.; Botstein, D. Cluster analysis and display of genome-wide expression patterns. Proc. Natl. Acad. Sci. USA 1998, 95, 14863-14868. [CrossRef] [PubMed]

38. Saldanha, A.J. Java Treeview- extensible visualization of microarray data. Bioinforma. Oxf. Engl. 2004, 20, 3246-3248. [CrossRef]

39. Moya, P.; Pedemonte, D.; Amengual, S.; Franco, M.; Sisterna, M. Antagonism and modes of action of Chaetomium globosum species group, potential biocontrol agent of barley foliar diseases. Boletin Soc. Argent. Bot. 2016, 51, 569-578. [CrossRef]

40. Osherov, N.; May, G.S. The molecular mechanisms of conidial germination. FEMS Microbiol. Lett. 2001, 199, 153-160. [CrossRef] [PubMed]

41. Deadman, M.L.; Cooke, B.M. A method of spore production for Drechslera teres using detached barley leaves. Trans. Br. Mycol. Soc. 1985, 85, 489-493. [CrossRef]

42. Scott, D.B. Identity of Pyrenophora isolates causing net-type and spot-type lesions on barley. Mycopathologia 1991, 116, 29-35. [CrossRef]

43. Alcorn, J.L. The Taxonomy of "Helminthosporium" Species. Annu. Rev. Phytopathol. 1988, 26, 37-56. [CrossRef] 
44. Mironenko, N.V.; Afanasenko, O.S.; Filatova, O.A.; Kopahnke, D. Genetic control of virulence of Pyrenophora teres drechs, the causative agent of net blotch in barley. Genetika 2005, 41, 1674-1680. [CrossRef]

45. Pană, M.; Cristea, S.; Manole, M.S.; Cernat, S.; Zala, C.; Berca, L.M. Research on the influence of temperature, light and culture media on growth and development of Pyrenophora teres fungus (in vitro). Agron. Ser. Sci. Res. Lucr. Stiintifice Ser. Agron. 2015, 58, 147-150.

46. Jayasena, K.W.; George, E.; Loughman, R.; Hardy, G. First record of the teleomorph stage of Drechslera teres $\mathrm{f}$. maculata in Australia. Australas. Plant Pathol. 2004, 33, 455-456. [CrossRef]

47. Barka, E.A.; Nowak, J.; Clément, C. Enhancement of chilling resistance of inoculated grapevine plantlets with a plant growth-promoting rhizobacterium, Burkholderia phytofirmans strain PsJN. Appl. Environ. Microbiol. 2006, 72, 7246-7252. [CrossRef] [PubMed]

48. Compant, S.; Reiter, B.; Sessitsch, A.; Nowak, J.; Clément, C.; Barka, E.A. Endophytic colonization of Vitis vinifera L. by plant growth-promoting bacterium Burkholderia sp. strain PsJN. Appl. Environ. Microbiol. 2005, 71, 1685-1693. [CrossRef] [PubMed]

49. Pinedo, I.; Ledger, T.; Greve, M.; Poupin, M.J. Burkholderia phytofirmans PsJN induces long-term metabolic and transcriptional changes involved in Arabidopsis thaliana salt tolerance. Front. Plant Sci. 2015, 6, 1-17. [CrossRef]

50. Su, F.; Jacquard, C.; Villaume, S.; Michel, J.; Rabenoelina, F.; Clément, C.; Barka, E.A.; Dhondt-Cordelier, S.; Vaillant-Gaveau, N. Burkholderia phytofirmans PsJN reduces impact of freezing temperatures on photosynthesis in Arabidopsis thaliana. Front. Plant Sci. 2015, 6, 1-13. [CrossRef]

51. Latgé, J.P. 30 years of battling the cell wall. Med. Mycol. 2017, 55, 4-9. [CrossRef]

52. Lee, J.I.; Choi, J.H.; Park, B.C.; Park, Y.H.; Lee, M.Y.; Park, H.M.; Maeng, P.J. Differential expression of the chitin synthase genes of Aspergillus nidulans, chsA, chsB, and chsC, in response to developmental status and environmental factors. Fungal Genet. Biol. 2004, 41, 635-646. [CrossRef]

53. Seidl, V. Chitinases of filamentous fungi: A large group of diverse proteins with multiple physiological functions. Fungal Biol. Rev. 2008, 22, 36-42. [CrossRef]

54. Orlean, P.; Funai, D. Priming and elongation of chitin chains: Implications for chitin synthase mechanism. Cell Surf. 2019, 5, 1-7. [CrossRef]

55. Chigira, Y.; Abe, K.; Gomi, K.; Nakajima, T. chsZ, a gene for a novel class of chitin synthase from Aspergillus oryzae. Curr. Genet. 2002, 41, 261-267. [CrossRef]

56. Choquer, M.; Boccara, M.; Gonçalves, I.R.; Soulié, M.-C.; Vidal-Cros, A. Survey of the Botrytis cinerea chitin synthase multigenic family through the analysis of six euascomycetes genomes. Eur. J. Biochem. 2004, 271, 2153-2164. [CrossRef] [PubMed]

57. Lenardon, M.D.; Munro, C.A.; Gow, N.A. Chitin synthesis and fungal pathogenesis. Curr. Opin. Microbiol. 2010, 13, 416-423. [CrossRef] [PubMed]

58. Brown, C.J.-L. Characterization of Specific Domains of the Cellulose and Chitin Synthases from Pathogenic Oomycetes; KTH Royal Institute of Technology: Stockholm, Sweden, 2015.

59. Munro, C.A.; Winter, K.; Buchan, A.; Henry, K.; Becker, J.M.; Brown, A.J.P.; Bulawa, C.E.; Gow, N.A.R. Chs1 of Candida albicans is an essential chitin synthase required for synthesis of the septum and for cell integrity. Mol. Microbiol. 2001, 39, 1414-1426. [CrossRef] [PubMed]

60. Rogg, L.E.; Fortwendel, J.R.; Juvvadi, P.R.; Steinbach, W.J. Regulation of expression, activity and localization of fungal chitin synthases. Med. Mycol. 2012, 50, 2-17. [CrossRef]

61. Ichinomiya, M.; Yamada, E.; Yamashita, S.; Ohta, A.; Horiuchi, H. Class I and class II chitin synthases are involved in septum formation in the filamentous fungus Aspergillus nidulans. Eukaryot. Cell 2005, 4, 1125-1136. [CrossRef] [PubMed]

62. Horiuchi, H. Functional diversity of chitin synthases of Aspergillus nidulans in hyphal growth, conidiophore development and septum formation. Med. Mycol. 2009, 47, 47-52. [CrossRef]

63. Lamichhane, A.K.; Garraffo, H.M.; Cai, H.; Walter, P.J.; Kwon-Chung, K.J.; Chang, Y.C. A novel role of fungal type I myosin in regulating membrane properties and its association with d-amino acid utilization in Cryptococcus gattii. MBio 2019, 10, 1-16. [CrossRef]

64. Nagahashi, S.; Sudoh, M.; Ono, N.; Sawada, R.; Yamaguchi, E.; Uchida, Y.; Mio, T.; Takagi, M.; Arisawa, M.; Yamada-Okabe, H. Characterization of chitin synthase 2 of Saccharomyces cerevisiae. Implication of two highly conserved domains as possible catalytic sites. J. Biol. Chem. 1995, 270, 13961-13967. [CrossRef]

65. Merzendorfer, H. Insect chitin synthases: A review. J. Comp. Physiol. 2006, 176, 1-15. [CrossRef] 
66. Guerriero, G. Putative chitin synthases from Branchiostoma floridae show extracellular matrix-related domains and mosaic structures. Genom. Proteom. Bioinform. 2012, 10, 197-207. [CrossRef]

67. Vandesompele, J.; de Preter, K.; Pattyn, F.; Poppe, B.; van Roy, N.; de Paepe, A.; Speleman, F. Accurate normalization of real-time quantitative RT-PCR data by geometric averaging of multiple internal control genes. Genome Biol. 2002, 3, 1-12. [CrossRef] [PubMed]

68. Fesel, P.H.; Zuccaro, A. $\beta$-glucan: Crucial component of the fungal cell wall and elusive MAMP in plants. Fungal Genet. Biol. 2016, 90, 53-60. [CrossRef] [PubMed]

69. Fontaine, T.; Hartland, R.P.; Beauvais, A.; Diaquin, M.; Latge, J.-P. Purification and characterization of an endo-1,3- $\beta$-glucanase from Aspergillus fumigatus. Eur. J. Biochem. 1997, 243, 315-321. [CrossRef] [PubMed]

70. Mouyna, I.; Hartl, L.; Latgé, J.-P. $\beta-1,3-$ glucan modifying enzymes in Aspergillus fumigatus. Front. Microbiol. 2013, 4, 1-9. [CrossRef]

71. Park, B.-C.; Park, Y.-H.; Yi, S.; Choi, Y.K.; Kang, E.-H.; Park, H.-M. Transcriptional regulation of fksA, a $\beta$-1,3-glucan synthase gene, by the APSES protein StuA during Aspergillus nidulans development. J. Microbiol. 2014, 52, 940-947. [CrossRef]

72. Samar, D.; Kieler, J.B.; Klutts, J.S. Identification and deletion of Tft1, a predicted glycosyltransferase necessary for cell wall $\beta-1,3 ; 1,4-$ glucan synthesis in Aspergillus fumigatus. PLoS ONE 2015, 10, e0117336. [CrossRef]

73. Jadhav, H.; Shaikh, S.; Sayyed, R. Role of hydrolytic enzymes of rhizoflora in biocontrol of fungal phytopathogens: An overview. In Rhizotrophs: Plant Growth Promotion to Bioremediation; Springer: Singapore, 2017; Volume 2, pp. 183-203.

74. Olanrewaju, O.S.; Glick, B.R.; Babalola, O.O. Mechanisms of action of plant growth promoting bacteria. World J. Microbiol. Biotechnol. 2017, 33, 1-16. [CrossRef]

(C) 2020 by the authors. Licensee MDPI, Basel, Switzerland. This article is an open access article distributed under the terms and conditions of the Creative Commons Attribution (CC BY) license (http://creativecommons.org/licenses/by/4.0/). 